\title{
Party Dissolutions and Democratic Consolidation: The Turkish Case
}

\section{Aylin Güney \& Filiz Başkan}

To cite this article: Aylin Güney \& Filiz Bașkan (2008) Party Dissolutions and Democratic Consolidation: The Turkish Case, South European Society \& Politics, 13:3, 263-281, DOI: 10.1080/13608740802346569

To link to this article: https://doi.org/10.1080/13608740802346569

册Published online: 24 Sep 2008.

Submit your article to this journal $\pi$

Џlll Article views: 322

4 Citing articles: 5 View citing articles 지다. 


\section{Party Dissolutions and Democratic Consolidation: The Turkish Case}

\section{Aylin Güney \& Filiz Başkan}

Political party competition constitutes an important component of democratic consolidation. In this respect, party dissolutions are generally regarded as impeding consolidation of democracies. This study addresses the relationship between party dissolutions and democratic consolidation, and offers an analysis of recent dissolutions of religiously and ethnically oriented political parties in Turkey. Drawing on Geoffrey Pridham's distinction between 'negative' and 'positive' democratic consolidation, the study concludes that the dissolutions of religiously oriented parties have contributed to the former while the dissolutions of ethnically oriented political parties have not. Meanwhile, the possible dissolution of the Adalet ve Kalkınma Partisi (AKP), representing 46.6 per cent of the population, would constitute a challenge to 'positive' democratic consolidation.

Keywords: Party Dissolution; Democratic Consolidation; Ethnically Oriented Parties: Religiously Oriented Parties; Turkey

Since the inception of the Republic in 1923, democratic consolidation in Turkey has been affected from time to time by either direct or indirect political interventions by the Turkish military (1961, 1971, 1980 and 1997) or by the dissolution of political parties for infringing the Constitution by posing a serious threat to its 'untouchable' founding pillars, namely secularism and the unity of the Turkish state. Evidence for the latter mainly referred to these parties' 'Islamist' or 'ethnic-separatist' character, or their 'communist/socialist' nature. Thus, since the very beginning, party politics in Turkey has been 'controlled' and 'shaped' to a great extent by a bureaucratic elite who consider themselves guardians of the Republic's constitutional principles. This elite comprises the military and leading bureaucratic institutions such as the High Court of Appeals, Constitutional Court, and Court of State, as well as some political parties like the Cumhuriyet Halk Partisi (CHP, Republican People's Party), which acted as the guardian of the Turkish state by upholding secularism and national unity. In the centre-periphery dichotomization of Şerif Mardin, this elite represented the 'centre', 
upholding Kemalist ideological values and basic principles upon which the Turkish state was founded, while the periphery represented the counter-official culture (Mardin 1973).

This article aims to analyse whether recent party dissolutions, especially of ethnically and religiously oriented political parties, contribute to democratic consolidation or not. Although the Turkish Constitutional Court also dissolved communist/socialist parties during the post-1980 period, there are several reasons to omit these from our analysis. First, in terms of electoral support, communist/socialist parties have always been at the margins of Turkish party politics. Second, especially since the end of the Cold War and the collapse of communist regimes, these parties have not posed a threat to the established order, as they have become even more marginalised. Rather, as Özbudun (1996) argues, the most important two challenges to democratic consolidation in Turkey have remained political Islam and ethnic separatism.

In fact, the origin of the cleavage between secular nationalism and ethnic and religious politics can be traced back to the early republican period. During the initial years of the Republic, conservative-religious circles struggled with secular-modernists over the nature of the newly emerging Turkish state. While the former wished to establish an Islamic constitutional regime in which the caliph ${ }^{1}$ would be the president of the assembly (Ahmad 1993, p. 52), the latter believed that the new Turkey should be transformed through a radical process of secularization into a modern nation state: 'an advanced and civilised nation in the midst of contemporary civilisation' (Ahmad 1993, p. 53). Accordingly, after abolishing the Caliphate in 1924, Mustafa Kemal and his supporters initiated a series of secularizing reforms (Zürcher 2005). At the same time, the secular-modernists aimed to create a unified/homogeneous nation, so they adopted an uncompromising approach towards ethnicity, especially Kurdish identity.

In this context, it is worth mentioning the Kurdish rebellion headed by Sheikh Sait that broke out in eastern Turkey in 1925, with the purpose of establishing an independent Kurdistan and restoring the Caliphate (Zürcher 2005, p. 171). The government dealt very harshly with the supporters of the rebellion: many of them were executed and more than 20,000 Kurds were deported from the southeast and resettled in western Turkey. However, despite the secular nationalist establishment's efforts to keep religious and ethnic identities under control, religious and ethnic groups have continued to be perceived as threats to a secular and unitary Turkish Republic. This has set the context for repeated closures of ethnic and religious political parties.

\section{Positive and Negative Democratic Consolidation}

Before examining the question of whether party dissolutions contribute to democratic consolidation or not, it is necessary briefly to discuss democratic consolidation. Leading scholars on democratic consolidation define it as 'a discernible process by which the rules, institutions, and constraints of democracy come to constitute 
"the only game in town," the one legitimate framework for seeking and exercising political power' (Diamond et al. 1997, pp. xvi-xvii). In this sense, the literature generally highlights the importance of the role played by political parties and party competition. Geoffrey Pridham, for example, argues that 'party competition is the hallmark of liberal democracy', highlighting the importance of parties, not only as agents in the institutionalization of a new democratic regime, but also as channels for developing electoral participation and hence for 'rooting' democratic values in society (Pridham 1990, p. 16). Excluding some political parties from party competition is thus assumed to hinder democratic consolidation.

In consolidated democracies, 'no significant national, social, economic, political, or institutional actors spend significant resources attempting to achieve their objectives by creating a nondemocratic regime or turning to violence or foreign intervention to secede from the state' (Linz and Stepan 1997, p. 6). That is, for democratic system to considered fully consolidated, the legitimacy of its key institutions must not be challenged by politically significant groups. So, one of the basic indicators of democratic consolidation is the absence of politically significant anti-system parties or social movements (Gunther et al. 1995, p. 13).

Pridham (1995, p. 169) terms the exclusion of anti-system parties or social movements 'negative consolidation'. Negative consolidation is achieved when the presence or impact of anti-system actors becomes numerically or politically insignificant. For example, they either become neutralised or opt out of the political game or convert to democratic politics. While negative consolidation implies the achievement of a significant or partial degree of consolidation, it is 'positive consolidation' that ultimately completes the process (Pridham 1995, pp. 168-169). Positive consolidation increases support for the democratic system by inculcating democratic norms and values in a population (Pridham 1995, p. 169). Since 'democratic consolidation may be said to have been achieved when there is evidence that the political culture is being "remade" in a system-supportive direction' (Pridham 1995, p. 169), political parties have an essential role as channels for 'rooting' the system in society and so providing a broader legitimization of the democratic regime. In other words, political parties can contribute to the consolidation of democracy by broadening its legitimacy, thereby reducing the potential for crises and breakdowns of the democratic regime in the long run (Gunther et al. 1995, p. 18). Thus, political parties play an important role in democratic consolidation as long as they do not have anti-system tendencies. In this context, it is essential to examine party dissolutions in Turkey regarding their effect on the positive and negative consolidation of Turkish democracy.

After providing a brief history of the cycles of party dissolution and (re)formation, the study will first address the extent to which the rhetoric and praxis of these replacement parties differed from their predecessors', and on what bases the Constitutional Court banned them again. Second, the article will discuss the degree to which the dissolution of these parties contributed to, or adversely affected, Turkey's democratic consolidation. 


\section{A Brief History of Party Dissolutions in Turkey}

Party dissolutions have been endemic to Turkish politics, stemming partly from the way the governing CHP wanted to secure the young Republic's future by 'excluding' some issues from the Turkish political scene. The initial years of the Republic witnessed two abortive attempts at multi-party democracy. However, the opposition Progressive Republican Party was dissolved in 1925, following allegations of ethnicreligious separatism, while the leader of the Free Republican Party decided to dissolve the party in 1930 upon Atatürk's withdrawal of his support. Turkey was subsequently ruled until 1946 by a single party, CHP.

The repressive policies of the Democrat Party between 1950 and 1960 made clear that individual rights and minority freedoms needed better protection, and that constitutional checks and balances were needed to restrain the legislature. It is against this background that the Turkish Constitutional Court emerged, following the 1960 military intervention and adoption of the 1961 Constitution, as one of the most powerful constitutional courts in Europe (Gençkaya 1998, p. 165).

The Constitutional Court has dissolved 24 parties, six during the pre-1980 period. ${ }^{2}$ The number of cases increased dramatically after the 1980 military intervention and the adoption of the 1982 Constitution. This was primarily because these parties' religious or ethnic-separatist characters were perceived as challenging democratic consolidation by infringing the Constitution. The 1982 Constitution (drafted by a committee of appointed experts and the National Security Council) laid down clear provisions allowing the Constitutional Court to dissolve anti-constitutional political parties. It was a clear sign of the re-assertion of the pillars of the Turkish Republic, particularly secularism and the territorial integrity of the state. The designers of the 1982 Constitution aimed to ensure that political parties behaved in accordance with these pillars. For instance, Article 68, Paragraph 4 views a political party as anti-constitutional when its statutes, rulebooks and activities are incompatible with the independence of the state, the integrity of state territory and of the nation, human rights, the principles of equality and the rule of law, national sovereignty or the principles of a democratic, secular Republic. ${ }^{3}$ Article 69 stipulates that the activities, internal regulations and operation of political parties should be in line with democratic principles', adding that 'a political party would be deemed to become the centre of such actions [mentioned in Article 68, Paragraph 4] only when such actions are carried out intensively by the members of that party or the situation is shared implicitly or explicitly by the grand congress, general chairmanship or the central decision-making or administrative organs of that party or by the group's general meeting or group executive board at the Turkish Grand National Assembly or when these activities are carried out in determination by the above-mentioned party organs directly. These articles thus formed the basis of the Constitutional Court's decisions to dissolve various religiously and ethically oriented parties perceived as infringing the Constitution.

Another important legal mechanism to assert the role of the bureaucratic elite was the change of the electoral system through the 1983 Election Law. This contributed to 
democratic consolidation through decreasing the degree of political polarization that had led to unstable coalition governments in the 1970s. Although a proportional representation system was retained, a percentage barrier (threshold principle) was introduced, whereby no party failing to receive ten per cent of the total vote could obtain parliamentary representation. This arrangement, among other effects, excluded extremist parties from the political arena and thus contributed to the bureaucratic elite's defence of the state. However, the ten per cent threshold has resulted in the exclusion of not only extremist but also mainstream parties from parliamentary representation. After this brief history and legal basis of party dissolutions, we will now explain why religiously and ethnically oriented parties and their successors were repeatedly dissolved.

\section{The Religiously Oriented Parties: From Refah to AKP}

The religiously oriented Refah Partisi (Welfare Party, hereinafter 'Refah') was founded in 1983 as 'political spokesman for religious voters' (Yildız 2003, p. 187) following the banning of the National Salvation Party, which, like all other parties, had been dissolved in the aftermath of the 1980 coup. Although Refah was able to garner 7.2 per cent of the popular vote in the 1987 general elections, it could not gain any seats in Parliament due to the above-mentioned ten per cent threshold. However, political Islam under the banner of Refah was greatly strengthened in the 1994 municipal and 1995 national elections. In 1994, Refah gained 28 municipalities, including İstanbul and Ankara. In 1995, the party garnered 21.3 per cent of the total votes and 158 out of 550 parliamentary seats. In June 1996, it formed a coalition government with the centre-right True Path Party. As Refah was the major partner in the coalition, it was agreed that the party's leader, Necmettin Erbakan, would become prime minister for the government's first two years. Refah's rise to power was considered both domestically and externally a worrisome development for the maintenance of Turkey's secular republican regime.

The Turkish military, which perceives itself as the guardian of the democratic and secular character of the Republic, initially maintained an 'above' politics approach and adopted a wait-and-see policy towards Refah's tenure. However, it voiced its extreme uneasiness about Refah's religiously oriented policies at the regular National Security Council (NSC) ${ }^{4}$ meeting of 28 February 1997. ${ }^{5}$ This meeting triggered a process that ended with the resignation of Refah from the government and the dismantling of the coalition. Meanwhile, on 21 May 1997, the Chief Prosecutor at the High Court of Appeals (hereinafter 'Chief Prosecutor') ${ }^{6}$ applied to the Constitutional Court to have Refah dissolved on the grounds that it had become a 'centre' (mihrak) of activities contrary to the principles of secularism. This case resulted in Refah's dissolution on 16 January 1998. In addition, its leader, Necmettin Erbakan, and five members of Parliament (MPs) and a mayor were banned from active politics for five years, convicted of making provocative statements in conflict with the secular and democratic principles of the Republic. ${ }^{7}$ 
The case for the dissolution of Refah was based on various activities and positions taken by the party and its leaders, which were used as evidence of Refah's intention to establish a state based on Sharia (Koğacioğlu 2004, p. 448). Examining Refah's policies while in power, one can identify radical aspects that were regarded as anti-secular by the bureaucratic elite. First, for example, one of the most controversial issues dividing the Turkish secular establishment and religiously oriented parties is the headscarf ban in state institutions. Secularists see the headscarf as a symbol of an outdated and oppressive religious code that has no place in state institutions, whereas religious parties view it as an expression of religious freedom. Refah was accused of supporting the struggle of female civil servants and university students to wear headscarves in state institutions, ${ }^{8}$ although this was contrary to NSC decisions and conflicted with the law establishing the unity of education. For instance, Erbakan's statement on 14 December 1995, '[university] chancellors are going to retreat before the headscarf when Refah comes to power', was taken by the Constitutional Court as evidence of Refah's support for the wearing of Islamic headscarves in state institutions.

Second, Erbakan hosted a Ramadan ${ }^{9}$ dinner for the leaders of various tarikats (religious orders) at the prime minister's official residence. The court found that this infringed the principle of secularism (Koğacioğlu 2003, p. 266). The court interpreted Erbakan's official hosting of these leaders in their religious attire, which is forbidden by the Dress Code, ${ }^{10}$ as the state giving official recognition to these religious orders, thus undermining the secular character of the Turkish Republic. ${ }^{11}$ The court also saw the Ramadan dinner as indicating that Refah was not neutral towards all religious groups, instead favouring Muslim Sunnis, although in its rhetoric the party had stressed that 'the state should be impartial towards all different religious groups. ${ }^{12}$

Thirdly, the court decided that remarks of certain MPs proved Refah intended to establish a Sharia-based regime. For instance, Hasan Hüseyin Ceylan, in a television interview broadcast on 24 November 1996, stated that 'the army says: "We can accept it if you're a supporter of the PKK [Kurdistan Workers Party], but a supporter of Sharia, never." Well you won't solve the problem with that attitude. If you want the solution, it's Sharia.' Similarly, on 8 May 1997, İbrahim Halil Çelik exclaimed in Parliament,

If you try to close the Prayer Leader and Preacher Schools while Refah is in government, blood will flow. It will be worse than in Algeria. I too would like blood to flow. That's how democracy will be installed in this country ... The army has not been able to deal with the 3,500 members of the PKK. How will it deal with six million Islamists? ... I will fight to the end to introduce Sharia. ${ }^{13}$

It might be questioned whether Refah's support for certain elements of Sharia can reasonably be claimed to be anti-democratic in the sense discussed by Pridham. However, the Constitutional Court's dissolution of Refah was approved by the European Court of Human Rights (ECHR). The latter agreed that 'Sharia is incompatible with the fundamental principles of democracy' and 'Refah's dissolution may be regarded as "necessary in a democratic society".' 14 Not all scholars, however, 
accept that Refah's support for elements of Sharia law indicate that it was against the democratic system. Kevin Boyle (2004, p. 9), for example, has argued that the ECHR, influenced by ' $9 / 11$ ', judged wrongly because its decision was incompatible with universal human rights and democracy.

However, despite the efforts of the bureaucratic elite to keep Refah out of politics, when it became clear that the party would shortly be dissolved, Refah members created a replacement, Fazilet Partisi (Virtue Party, hereinafter 'Fazilet'), on 17 December 1997. Although retaining almost all former deputies of Refah, Fazilet's stance in some respects appeared more moderate than Refah's (Öniş 2001, p. 287), which allowed it to participate in Turkish politics. However, it remained unclear whether the reason behind Fazilet's moderated rhetoric reflected a genuine aspiration to position itself within the centre of the Turkish political spectrum. Since Fazilet had some problems in terms of defining its identity, it eventually became 'a party without politics' (Yavuz 2000 , p. 40). On the one hand, it had to deny it was a continuation of Refah, since, according to Article 69, Paragraph 7 of the Constitution, ${ }^{15}$ a party that is a reproduction of a previously banned party must also be dissolved. On the other hand, it was difficult for Fazilet to argue that it was different from Refah because it kept almost all Refah deputies as well as rank-and-file members.

Although it tried to avoid radical stances, Fazilet could not avoid dissolution by the Constitutional Court on 22 June 2001, on the grounds that it had become a 'centre of activities contrary to the principles of secularism. ${ }^{16}$ In addition to banning the party, the court stripped Nazlı Ilıcak and Bekir Sobac1 of their parliamentary status, and Merve Kavakçı, Nazlı Ilıcak, Ramazan Yenidede and Bekir Sobacı were banned from active politics for five years, since their speeches had caused Fazilet's dissolution. ${ }^{17}$ As with Refah's case, rather than the party programme, it was the speeches and actions of some party members which played the greatest role in its dissolution. In Fazilet's case, the most controversial issue concerned Merve Kavakçı's headscarf. Although she had previously declared that she would not remove her headscarf under any circumstances, Fazilet's leadership still nominated her as a parliamentary candidate. After becoming an MP in the 18 April 1999 national elections, Kavakçı appeared at the General Assembly on 3 May 1999 to take the parliamentary oath with her headscarf on. The Constitutional Court accepted this illegal act as evidence that Fazilet was a centre of anti-secular activities.

The speeches of some Fazilet MPs regarding Kavakçı's case also contributed to the court's decision. For instance, Nazlı Ilıcak, a female Fazilet MP, stated in a meeting in Kayseri on 10 October 1998 that

When Fazilet comes to power the oppression of (Turkish women wearing) the headscarf will end. Do you know how? Because the Fazilet Party will make ladies with headscarves enter Parliament (and one day) there will be minister(s) with headscarves on, (serving) this country. ${ }^{18}$

Ilıcak also accompanied Kavakçı down the aisle in the Assembly with her headscarf on, indicating her explicit support for Kavakçı's actions. The court perceived Ilıcak and 
Kavakçı's actions as primarily aimed at forcing Parliament to have a general debate on the headscarf issue. Another Fazilet MP, Bekir Sobac1, had supported the illegal activities of female students expelled from some faculties of medicine in Istanbul for refusing to remove headscarves in class. He met these students in Ankara, organised a press conference and arranged visits to political parties in Parliament. Another party member, Ramazan Yenidede, was accused of inciting hatred and enmity regarding the implementation of the ban on headscarves in state institutions and schools. ${ }^{19} \mathrm{He}$ had claimed that the ban was an act of oppression and tyranny.

It is important to note that, from its conception, Fazilet suffered an identity crisis, which was a major point of contention within the party itself, as cleavages appeared between 'reformists' and 'traditionalists'. At the first Party Congress on 14 May 2000, Abdullah Gül, from the reformist wing, announced his candidacy against party leader Recai Kutan, who was known to be a close follower of Erbakan. Despite Kutan's narrow victory (633 to 521), it was a significant turning point, since it was the first time that there had been more than one candidate running for party leadership in the history of political Islam in Turkey. The reformist wing was aware that the old politics of Erbakan only created obstacles to their further development (Ülsever 2001). This crisis culminated in a split, which was officially sealed with the formation of a new party, Saadet Partisi (SP, Felicity Party), led by Recai Kutan. The new party, believed to be ruled from behind the scenes by former prime minister Erbakan, represented the traditionalist wing and included some 50 of the 100 deputies of the outlawed Fazilet.

Fazilet's reformist wing rallied behind the former Istanbul mayor Recep Tayyip Erdoğan, who launched the Adalet ve Kalkınma Partisi (AKP, Justice and Development Party) on 14 August 2001. Erdoğan had been trying to project a different image of himself as someone who emphasised agreement rather than disagreement, and was trying to appeal to a broader electorate instead of addressing only religiously oriented voters. ${ }^{20} \mathrm{He}$ defined the AKP as 'a mass-based party founded on the fundamentals of conservatism' and the single power on the centre-right of the political spectrum. ${ }^{21}$ In this sense, AKP has tried to form a political identity based on the notion of 'conservative democracy' (Akdoğan 2003), indicating its determination to distance itself from the other religiously oriented parties. Metin Heper (2003, p. 131), for example, noted that 'since its inception AKP has displayed stronger pro-system features than its predecessors' and Yilmaz (2004, p. 617) defined AKP 'as [primarily] a conservative political party made up of members who have strong Islamic feelings'. Other observers share this view of AKP as exemplifying the transformation of a religiously oriented party into a centre-right one (Coşar \& Özman 2004, pp. 67-68; Öniş 2006; Özbudun 2006; Kalaycioğlu 2007; Keyman \& Öniş 2007).

In contrast to its predecessors, AKP's rhetoric was 'moderate' from the start. The points mentioned in the party programme lack a specifically Islamic character: they can even be found in the programmes of other centre-right or centre-left parties (Öniş 2000). For instance, AKP's economic policies can be regarded as liberal and it supports integration of the Turkish economy into the global economy. Moreover, it has followed a pro-Western foreign policy. In a radical break with previous religiously oriented parties, 
as soon as it came to power after the 2002 general elections, AKP became an ardent supporter of Turkey's European Union (EU) membership. This risked alienating some of its voters, most of whom had supported previous religiously oriented parties and so might be against Turkey's EU integration (Grigoriadis 2004, p. 67). From the outset, Erdoğan stated that his party would do its best to meet EU membership criteria and get a date for membership negotiations at the Copenhagen summit in December $2002 .^{22}$ Under AKP rule, between 2002 and 2004, five 'harmonization packages' were passed through Parliament thanks to AKP's absolute majority. Serious measures were taken to end torture, eliminate legal restrictions on freedom of expression, freedom of association and freedom of the media and assembly and allow TV broadcasting in local mother tongues other than Turkish on both public and private channels.

Thus, there appear to be striking differences between AKP's rhetoric and that of its predecessors. There may be several reasons for this moderation, related to the changing dynamics of domestic and international politics. However, we can claim that one of the reasons relates to the AKP leadership's realization that their party could only survive through a more moderate rhetoric. As Özbudun (2006, p. 547) puts it, 'as a result of the closure of the RP and FP, a group of former Islamist politicians seems to have reached the conclusion that challenging the secular state in Turkey is a dead-end'. Furthermore, as already mentioned, the ECHR had upheld the Turkish Constitutional Court's decision regarding Refah, ruling that Refah had declared its intention to institute Sharia, which would be incompatible with fundamental democratic principles. The AKP leadership therefore realised that they would not get international support for anti-democratic activities.

AKP's general election victory on 3 November 2002 made it the first party since 1987 to form a single-party government. It is interesting to note that support for AKP, which represented the moderate wing of the previous religiously oriented party, increased dramatically. In contrast, SP, which had remained traditional, got a marginal vote of $2.5 \%$. In the 2007 general elections, AKP experienced a further jump in its vote to 46.6 per cent of the total votes and 341 seats out of 550 in Parliament. Significantly, for the first time in 53 years, a ruling party won an election victory with an increased vote in Turkey.

However, despite AKP's efforts to keep within the Constitution, the Chief Prosecutor applied to the Constitutional Court on 14 March 2008 to dissolve it on the grounds that it had become a 'centre' of activities contrary to the principles of secularism, and to ban 71 of its members from seeking elected office for five years. The main issue behind this case was two constitutional amendments introduced by AKP and the Nationalist Action Party on 9 February 2008 to lift the headscarf ban in universities. The Chief Prosecutor cited these constitutional amendments in his indictment against the AKP as evidence that it was a centre of anti-secular activities. Meanwhile, the Constitutional Court cancelled both amendments on 5 June 2008, on the grounds that they violated the Constitution's secular principles. Some argued that this decision could be regarded as an indication that the Constitutional Court would then dissolve AKP.

Our account so far indicates that religiously oriented parties move towards the centre-right of the political spectrum following dissolutions. Thus, it can be proposed 
that dissolutions of religiously oriented parties have contributed to 'negative consolidation', since the dissolutions have unintentionally allowed the emergence of more moderate political parties converted to democratic politics in the manner Pridham proposes. Nevertheless, it can be maintained that the possible dissolution of AKP, representing 46.6 per cent of the vote share, would constitute a challenge to 'positive consolidation', the process that ultimately completes the process of democratic consolidation. AKP has adopted a more moderate approach and made many reforms to democratise Turkey, but the bureaucratic elite still has suspicions about the moderated rhetoric of the party and interprets every activity of the party in a negative manner. In this context, it can be claimed that the emergence of moderate parties is not enough for democratic consolidation: attitudes within the bureaucratic elite need to change too. In addition, the judiciary's attempt to dissolve a political party holding 46.6 per cent of the vote could endanger the system of checks and balances necessary in a consolidated democracy.

\section{Ethnically Oriented Parties: From HEP TO DTP}

The Constitutional Court has not only ruled against religiously oriented parties, but also judged that a series of ethnically oriented parties infringed the principle of the territorial integrity of the unitary state. ${ }^{23}$ Article 68, Paragraph 4 of the 1982 Constitution states that all political parties embrace the whole nation, and should not be based, among other things, on regionalism and ethnicity.

Despite the post-1980 state ideology of 'Turkish-Islamic synthesis', radical Kurdish groups had intensified their activities under the banner of the illegal PKK, led by Abdullah Öcalan. The PKK described itself as Marxist-Leninist, and adopted leftwing and anti-imperialist rhetoric, opposing 'Turkish imperialism' in 'Turkish Kurdistan'. It declared its goal as the creation of a unified and independent Kurdish state (Barkey \& Fuller 1998) and engaged in terrorist activities to accomplish that goal. From 1990 onwards, legal ethnically oriented political parties, planning to run in parliamentary elections, began to appear.

The first was Halkın Emek Partisi (HEP, People's Labour Party), formed on 7 June 1990. HEP's rhetoric and programme were quite cautious and moderate during its first year. Its programme made a careful, though implicit, distinction between itself and the PKK, stating that it aimed to solve the Kurdish problem through peaceful and democratic methods in line with the Universal Declaration of Human Rights, the European Convention on Human Rights, and the statutes of the Helsinki Final Document' (Watts 1999, p. 636). However, for the Turkish bureaucratic elite, HEP's accommodating party rhetoric seemed more radical and threatening when issues like the Kurds' perceived right to self-determination started to be raised frequently, together with heavy criticism of the Turkish state. HEP's 1992 party programme clearly reflected this new radical stance, where 'Kurdishness' and the 'Kurdish problem' were frequently repeated. A second shift towards greater radicalism was seen after the 1991 elections, when more radical yet less experienced Kurdish deputies entered politics, 
carrying PKK flags and pictures of the PKK leader to HEP meetings. As moderates within the party were unable to exert control over the radical wing, the party as a whole came to be perceived as closely linked to the illegal PKK. This led to the Constitutional Court banning the party on 14 July 1993. The court additionally stripped Fehmi Işıklar, Feridun Yazar, Ahmet Karataş and İbrahim Aksoy of their MP status for causing HEP's dissolution by their words and deeds. ${ }^{24}$

The court was particularly critical of HEP for 'seeking to divide the Turkish nation in two, with Turks on one side and Kurds on the other, with the aim of establishing separate states' and of 'seeking to destroy national and territorial integrity. ${ }^{25}$ When the dissolution case was filed, members of HEP founded Özgürlük ve Demokrasi Partisi (ÖZDEP, Freedom and Democracy Party) as a 'replacement' party on 19 October 1992. However, the Chief Prosecutor applied to the Constitutional Court to dissolve ÖZDEP too, on the grounds that its programme also sought to undermine the territorial integrity and secular nature of the state and the unity of the nation. ÖZDEP was formally dissolved by the Constitutional Court on 23 November 1993.

ÖZDEP was succeeded by Demokrasi Partisi (DEP, Democracy Party), founded in May 1993 by a group of politicians that included many former ÖZDEP members and many prominent HEP parliamentarians, and generally viewed as a replica of HEP (Muller 1996, p. 187). Under DEP, the leadership cadres became increasingly divided over how much support to give to the PKK. Eventually, a division emerged between a moderate flank and a more powerful radical group led by Hatip Dicle, a deputy from the sout-eastern city of Diyarbakır (Watts 1999, p. 638). For example, when in February 1994 a PKK bomb killed a group of military cadets in a railway station near Istanbul, Dicle declared, 'In war, everyone in uniform is a target. ${ }^{26} \mathrm{He}$ also argued that the PKK was a political, not a terrorist, organization (Watts 1999, p. 648). Another leading DEP member referred to the PKK's violent activities as a struggle for 'an independent and unified Kurdish state', and demanded a political solution to the Kurdish question (Muller 1996, p. 188). Consequently, in March 1994, the parliamentary immunity of DEP deputies of Kurdish origin was removed. Six of them were arrested, convicted and sentenced to 15 years' imprisonment.

On 16 June 1994 the Constitutional Court dissolved DEP for activities that infringed the territorial integrity of the state and the unity of the nation. In addition to banning DEP, the court stripped 13 DEP deputies of their parliamentary status, since their speeches and activities had caused DEP's dissolution. For instance, the court cited party chairman Yaşar Kaya's statements in a speech on 29 May 1993 in Bonn. He had stated that

One of the things that the Republic could not accomplish was to find a peaceful solution to the Kurdish problem... Despite the developments in the world, Kurds always lived in exile, were imprisoned, denied and died. At the present time, it is impossible to deny that Kurds exist. It has been the armed struggle that brought this problem to the Kurdish and Turkish people's attention and also to the world's attention in general. 
At another speech in Erbil, Iraq on 15 August 1993, he had said, 'Our people give us their daughters and sons for the sake of our cause. $40-50$ of them become martyrs in the mountains every day... The Kurds have taken an oath. Our oath is death [for independence]. ${ }^{27}$ The court also ruled that DEP breached the Constitution concerning the language of the Turkish Republic. It cited parts of DEP's declaration entitled Democracy Party's Call for Peace, stating that 'the Kurds should be able to use and develop their own language, culture and art to be able to express themselves' and that 'the right to education in mother tongue should be granted and broadcasting in Kurdish should be possible'. HEP and DEP's ambiguous position regarding the solution of Kurdish problem has been pointed out by Kirişçi and Winrow (1997, pp. 146-147). They argue that

both HEP and DEP stressed that the Kurdish question should be solved by democratic and peaceful means. But the exact nature of the solution was never clearly defined. Both parties gave the impression that the minimum they would settle for would be cultural concessions to Kurdish ethnicity. However, the deputies from both parties also seemed to allude to a 'binational state' as they emphasised a 'Turkish and Kurdish ethnic equality based on law'.

The next ethnically oriented party, Halkın Demokrasi Partisi (HADEP, People's Democracy Party), ${ }^{28}$ was founded in May 1994 by Murat Bozlak. HADEP did not participate in the 1994 municipal elections, claiming that the state's intimidating tactics made it very difficult for the party to stage a free campaign (Barkey \& Fuller 1998, p. 86). However, the party participated in the 1995 and 1999 national elections, gaining 4.2 per cent and 4.7 per cent of the votes, respectively (Bozarslan 1996). Due to the ten per cent threshold, however, it could not achieve parliamentary representation. It is important to note that in both elections the party was successful in the southeast, densely populated by citizens of Kurdish origin. It won municipalities in seven cities there, including the biggest city of the region, Diyarbakır, with 62.5 per cent of the vote.

At first, HADEP adopted a moderate discourse, distancing itself from the PKK and calling for a peaceful resolution to the conflict between the Turkish military and the PKK. For example, in September 2001, HADEP leader Bozlak stated, 'It was claimed that HADEP has been the political arm of the PKK. It is not true ... HADEP is not a separatist party. Neither is it an ordinary nationalist party. Ours is a leftist mass party. We have never perceived ourselves as a Kurdish Party. ${ }^{29}$ HADEP also chose not to join the so-called Kurdish parliament-in-exile in the Netherlands. HADEP seemed to be moving towards a more politically moderate stance, stressing that its candidates were technocrats rather than militants, ${ }^{30}$ that it no longer wanted to be labelled a Kurdish party, and that its party programme encompassed a wide range of issues and addressed all the major problems Turkey faced. ${ }^{31}$ Consequently it avoided becoming a target of the bureaucratic elite, at least until its disastrous party Congress in June 1996, where masked men let the Turkish flag fall to the floor and raised the PKK banner in its place. Following this, party officials, including Bozlak, were arrested, and all but one charged with belonging to or leading an illegal armed group. 
One gets the impression with HADEP, as with HEP and DEP, of a tug-of-war between moderates and radicals. Most probably due to fear of dissolution, at HADEP's November 1998 party Congress, leaders advised delegates to remain calm, and worked closely with police to ensure that radical incidents similar to those at the 1996 Congress would not take place. ${ }^{32}$ Nevertheless, in January 1999, the Chief Prosecutor asked the Constitutional Court to ban the party on the grounds that HADEP had an 'organic link' with the PKK and was acting as a front for it. HADEP was dissolved on 13 March 2003 for becoming a centre of activities contrary to the principle of the indivisible integrity of the state and nation. ${ }^{33}$ The court also banned 45 HADEP members, including its founders, from becoming a member, founder, administrator or inspector of any political party for five years.

The speeches and actions of its leader and some party members played the greatest role in HADEP's dissolution. A number of examples were given in evidence. The Constitutional Court regarded the press releases of the PKK's news agency and proPKK journals and magazines found in HADEP members' offices as evidence of a close relationship between HADEP and the PKK. The party Congress in June 1996 was also given as evidence: the court mentioned that HADEP's leadership had done nothing to end provocative actions at this congress. HADEP officials' open support for the PKK, and hunger strikes staged in support of imprisoned PKK leader Abdullah Öcalan were other reasons behind the court's ruling. The Constitutional Court cited party chairman Murat Bozlak's speech in front of a poster of Öcalan's and a PKK flag at the party Congress on 23 June 1996. Bozlak had stated in his speech,

The Kurdish people have confidence in HADEP since HADEP is a part of the Kurdish people ... [The state] denies the existence of the Kurds who also took part in the independence war of this country. The Kurds are deprived of their rights to speak in their own language and develop their own culture ... It is not possible to reach a solution by occupation ... The Kurds have been removed from their villages and their homes which have been burned and destroyed ... We have to change the 1982 Constitution. The Kurdish identity should be recognised. ${ }^{34}$

When it became clear that the party would shortly be dissolved, HADEP campaigned under Demokratik Halk Partisi (DEHAP, Democratic People's Party) during the 3 November 2002 elections and some 20 senior HADEP officials resigned to join this party. The 2002 general election results showed a slight increase in DEHAP votes compared with HADEP, but it was still not possible to send representatives to the parliament due to the ten per cent threshold. The Chief Prosecutor then asked the Constitutional Court to ban DEHAP, which largely mirrored HADEP's views, alleging that the party was against the democratic Republic, equality and the laws and principles of the state.

The leaders of DEHAP decided to dissolve the party in December 2005 and join Demokratik Toplum Partisi (DTP, Democratic Society Party), founded in October 2005 by the Democratic Society Movement, which had been formed by former DEP deputies who had been stripped of their MP status by the Constitutional Court. In order to circumvent the ten per cent threshold, the DTP candidates ran as independents in the 2007 general elections. Twenty candidates were elected as deputies, who then joined the DTP. 
Like its predecessors, it has not distanced itself from the PKK. For example, it refused to declare the PKK a terrorist organization. Soon after the 2007 general elections, on 16 November 2007 the Chief Prosecutor asked the Constitutional Court to dissolve DTP on the grounds that speeches and actions by party leaders proved that the party had become a centre of activities against the territorial integrity of the state and the unity of the nation, and to ban 221 of its members, including eight current MPs, from being members of a political party for five years.

This cycle of closures and party formations in Turkey suggests that, in contrast to religiously oriented parties, dissolution has not made ethnically oriented parties move towards the centre of the political spectrum, due to reasons that will be discussed below. Therefore, we can argue that the dissolutions of ethnically oriented parties, unlike those of the religiously oriented ones, have not contributed even to 'negative consolidation' of democracy in Turkey. In this context, it can be proposed that in Turkey's case party dissolutions have a differential impact on religiously and ethnically oriented parties.

There are several reasons for this differential impact. First, following the adoption of neo-liberal policies at the beginning of the 1980s, we have witnessed the rise of a new Muslim bourgeoisie and private companies known as 'Anatolian tigers' (Taşkın 2008). The support of this Islamic business community has been essential for the moderation of AKP, since they 'have a lot to lose from open confrontation with the secular establishment and the state elites' (Öniş 2006, p. 212). No kind of Kurdish business community has emerged, however, to push the ethnically oriented parties towards the centre. Second, Refah garnered 21.3 per cent of total votes and 158 seats in Parliament and participated in a coalition government, making it a potential party of power. Aware of this, AKP leaders moderated their rhetoric in order to establish a centre-right party able to embrace all Turkish society. ${ }^{35}$ In contrast, the leaders of ethnically oriented parties do not appear intent on establishing a party located at the centre of the political spectrum, since they exist as a party of protest. Third, related to the previous point, it can be claimed that the religiously oriented parties, especially AKP, are national parties appealing across Turkish society, whereas ethnically oriented parties are regional parties, aimed at getting especially the support of Kurdish people from southeastern Turkey, as the above-mentioned election results indicate.

The ECHR has not responded to all dissolutions in the same way. Upon HEP's closure, its leader, Feridun Yazar, and two deputies, Ahmet Karataş and İbrahim Aksoy, applied to the ECHR on 24 September 1993. Unlike the Refah case, the ECHR decided on 9 July 2002 that, 'as the HEP did not advocate any policy that could have undermined the democratic regime in Turkey and did not urge or seek to justify the use of force for political ends', its dissolution violated Article 11 of the Convention which emphasised the right of freedom of association. ${ }^{36}$ For the ECHR, the demands of HEP regarding the right to self-determination and recognition of language rights are compatible with the basic principles of democracy. Since the ethnically oriented parties think similarly, their rhetoric did not change much upon their dissolution. It can be argued that the leaders of these parties believe that to conform to what the Constitutional Court wants would politically emasculate them. 


\section{Party Dissolutions in Retrospect: Contribution or Impediment to Consolidation of Democracy?}

The extensive legal mechanisms and measures protecting the Turkish Republic's fundamental principles reflect the bureaucratic elite's fear of 'political Islam' and 'ethnic separatism'. Therefore, religiously and ethnically oriented parties have been always under the bureaucratic elite's close scrutiny. It is important to note that religiously and ethnically oriented parties in Turkey are not banned immediately after their establishment. Instead, the bureaucratic elite generally adopts a policy of waitand-see rather than immediately excluding these parties from the political arena. As seen above, the speeches and acts of party members, rather than party programmes, tend to constitute the reason for party dissolutions. The most important effect of dissolutions, easily observed in the lineages of both religiously and ethnically oriented parties, is the repeated party 'reincarnations' under different guises: banned parties simply reproduce themselves under different names and symbols.

The bureaucratic elite's primary aim in dissolving parties is to safeguard the secular character and territorial integrity of the country. Although both religiously and ethnically oriented parties have been forced out of Turkey's political game, only the dissolutions of religiously oriented parties have contributed to the negative consolidation of Turkish democracy. The dissolutions of these parties have allowed the emergence of more moderate political parties, moving towards the centre-right of the political spectrum and willing to play within the rules of Turkey's democratic game. It can be proposed that one important reason, among others, for this transformation is their members' fear of dissolution and political exclusion. In contrast, ethnically oriented parties have been unable to move towards the centre of the political spectrum upon dissolution, due to the reasons discussed above. Thus Pridham's account does not apply to their case. This leads us to argue that party dissolutions have differential impacts on religiously and ethnically oriented parties in contributing to democracy in Turkey.

Moreover, to be able to talk of democratic consolidation, in addition to 'negative consolidation', there also needs to be 'positive consolidation'. Party dissolutions may contribute to democratic consolidation only when replacement parties begin acting as channels for the development and rooting of democratic values in society. However, as the recent case against AKP reveals, attitude changes in replacement parties are necessary, but not enough, for democratic consolidation. Some argue that the positive consolidation of Turkish democracy will also require a change of attitude in the bureaucratic elite. Belge (2006, p. 656) maintains that since the mid-1990s the Constitutional Court, by closing down those political parties representing excluded identities such as Kurdish or Islamic groups, has been an obstacle to a more pluralistic democracy. As Somer (2007, p. 1280) argues, 'democratic consolidation requires that the major political actors build a certain degree of mutual trust. Actors must believe that other actors will not use democracy to pursue goals that are fundamentally threatening to them.' However, as discussed above, when dissolved parties re-open as 
'replacement' parties, the bureaucratic elite harbours suspicions about the sincerity of their moderated rhetoric, and seems determined to interpret anything they say or do (or anyone at all associated with them) in the most negative way possible. This attitude creates mistrust among political actors. The leaders of religiously and ethnically oriented parties constantly experience a threat of dissolution, so they have little trust in the bureaucratic elite and other political parties. This causes a polarization at both political and societal levels. It can be argued that, in the long run, such polarization constitutes a challenge to democratic consolidation by preventing the inculcation of trust and democratic values in society. Ultimately, as the accounts of the dissolution of religiously and ethnically oriented parties reveal, democratic consolidation requires not only religiously and ethnically oriented parties but also secular nationalist parties and the bureaucratic elite to internalise democratic values and act in accordance with the basic principles of democracy.

\section{Acknowledgements}

The authors are grateful to the anonymous referees and to the editors of the journal for their comments on previous versions of the article. Aylin Güney gratefully acknowledges the support provided by the Turkish Academy of Sciences (GEBIP) programme for the research for this article.

\section{Notes}

[1] A caliph is a spiritual leader of the Muslim community. After the first four caliphs following the death of Prophet Muhammad, there was a struggle within the Muslim community over the use of the title of Caliph. Although Selim I assumed the title of Caliph following the Ottomans' conquest of Egypt, the Ottoman sultans did not use the title until the last quarter of the eighteenth century. However, following the establishment of the Turkish Republic, the Caliphate was abolished in 1924 as part of a radical secularization process.

[2] < http://www.anayasa.gov.tr/KARARLAR/SPKAP.htm $>$.

[3] Article 2 of the Turkish Constitution refers to the secular character of the Turkish Republic by stipulating that 'the Republic of Turkey is a democratic, secular and social state governed by the rule of law'. The definition of secularism is provided in Article 10, which states, 'All individuals are equal without any discrimination before the law, irrespective of language, race, colour, sex, political opinion, philosophical belief, religion and sect, or any such considerations.'

[4] The NSC during that period was composed of the president, the prime minister, the chief of the General Staff, the ministers of justice, national defence, interior and foreign affairs and the commanders of the branches of the armed forces and the gendarmerie. This body sets national security policy and coordinates all activities related to mobilization and defence.

[5] For an elaboration of the period from the establishment of the coalition government of Refah and the TPP to the 27 February 1997 National Security Council meeting, see Heper and Güney (2000).

[6] The Chief Prosecutor asks the Turkish Constitutional Court to dissolve a political party based on the evidence produced by scrutinizing its programme and activities. After written and oral defence of the party, the Constitutional Court decides by three-fifths majority whether the party will be dissolved or not on the basis of the Turkish Constitution and Political Parties Law. In other words, seven of eleven members of the Court have to vote for a party's dissolution. 
[7] < http://www.anayasa.gov.tr/KARARLAR/SPK/K1998/K1998-01.htm>.

[8] According to the present dress code in Turkey, women wearing headscarves are not allowed in state institutions and universities.

[9] The holy month when the Muslims fast.

[10] In 1925, since the establishment of the Turkish Republic, there has been a law regarding the Dress Code in which religious attire can be used only by people serving religious duties.

[11] < http://www.anayasa.gov.tr/KARARLAR/SPK/K1998/K1998-01.htm>.

[12] Refah Partisi Programme1, Ankara, 1983.

[13] < http://www.anayasa.gov.tr/KARARLAR/SPK/K1998/K1998-01.htm>.

[14] < http://cmiskp.echr.coe.int/tkp197/view.asp?action $=$ html\&key=34650\&portal = hbkm\&source $=$ external\&table $=285953$ B33D3AF94893DC49EF6600CEBD49 $>$.

[15] This article was amended on 4 October 2001 by the Turkish Grand National Assembly, in order to meet the criteria for Turkey's EU membership.

[16] < http://www.anayasa.gov.tr/KARARLAR/SPK/K2001/K2001-02.htm>.

[17] Ibid.

[18] Ibid.

[19] Ibid.

[20] Hürriyet, 28 August 2001, < http://webarsiv.hurriyet.com.tr/2001/08/28/21385.asp > .

[21] Turkish Daily News, 12 January 2004.

[22] Turkish Daily News, 8 November 2002.

[23] For a detailed analysis of a historical evaluation of how the Turkish state perceives the Kurdish issue, see Yeğen (1999).

[24] < http://www.anayasa.gov.tr/KARARLAR/SPK/K1993/K1993-01.htm>.

[25] Ibid.

[26] Sabah, 17 February 1994.

[27] Ibid.

[28] For a more detailed analysis of HADEP, see Güney (2002).

[29] Milliyet, 3 September 2001, < http://www.milliyet.com.tr/2001/09/03/siyaset/asiy.html>, interview by Derya Sazak.

[30] Milliyet, 21 September 1998, < http://www.milliyet.com.tr/1998/09/21/index.html>, Ruşen Çakır.

[31] Ibid.

[32] Reuters, 18 November 1998.

[33] Resmi Gazete (Official Gazette), 19 July 2003, on < http://rega.basbakanlik.gov.tr/>.

[34] Ibid.

[35] Hürriyet, 28 August 2001.

[36] < http://cmiskp.echr.coe.int/tkp197/view.asp?action $=$ html\&key=34130\&portal= hbkm\&source $=$ external\&table $=285953$ B33D3AF94893DC49EF6600CEBD49>.

\section{References}

Ahmad, F. (1993) The Making of Modern Turkey, Routledge, London/New York.

Akdoğan, Y. (2003) Muhafazakar Demokrasi [Conservative Democracy], AK Parti Yayınları, Ankara.

Barkey, H. J. \& Fuller, G. E. (1998) Turkey's Kurdish Question, Rowman \& Littlefield, Lanham, $\mathrm{MD} /$ Boulder, CO.

Belge, C. (2006) 'Friends of the court: the republican alliance and selective activism of the Constitutional Court of Turkey', Law and Society Review, vol. 40, no. 3, pp. 653-692.

Boyle, K. (2004) 'Human rights, religion and democracy: the Refah Party case', Essex Human Rights Review, vol. 1, no. 1, pp. 1-16.

Bozarslan, H. (1996) 'Turkey's elections and the Kurds', Middle East Report, no. 199, pp. 16-19. 


\section{A. Güney \& F. Başkan}

Coşar, S. \& Özman, A. (2004) 'Centre-right politics in Turkey after the November 2002 general election: neo-liberalism with a Muslim face', Contemporary Politics, vol. 10, no. 1, pp. 57-74.

Diamond, L. (1997) 'Introduction: in search of consolidation', in Consolidation the Third Wave Democracies: Themes and Perspectives, eds L. Diamond, M. F. Plattner, Y. Chu \& H. Tien, Johns Hopkins University Press, Baltimore/London, pp. xii-xlvii.

Gençkaya, Ö. F. (1998) 'The Turkish Constitutional Court and dissolution of political parties: comparative perspectives', in Suna Kili'ye Armağan: Cumhuriyete Adanan bir Yaşam, Boğaziçi Üniversitesi Yayınları, İstanbul, pp. 165-184.

Grigoriadis, I. N. (2004) 'AKP and the paradox of Islamic Europhilia', Turkish Policy Quarterly, vol. 3, no. 1 , pp. $65-70$.

Gunther, R., Jürgen Puhle, H. \& Diamandouros, P. N. (1995) 'Introduction', in The Politics of Democratic Consolidation, eds R. Gunther, H. Jürgen Puhle \& P. N. Diamandouros, Johns Hopkins University Press, Baltimore/London, pp. 1-32.

Güney, A. (2002) 'The People's Democracy Party', in Political Parties in Turkey, eds B. Rubin \& M. Heper, Frank Cass, London/Portland, pp. 122-137.

Heper, M. (2003) 'The victory of the Justice and Development Party', Mediterranean Politics, vol. 8, no. 1 , pp. $127-134$.

Heper, M. \& Güney, A. (2000) 'The Military and the consolidation of democracy: the recent Turkish experience', Armed Forces and Society, vol. 26, no. 4, pp. 639-645.

Kalaycıoğlu, E. (2007) 'Politics of conservatism in Turkey', Turkish Studies, vol. 8, no. 2, pp. 233-252.

Keyman, F. \& Öniş, Z. (2007) 'Globalisation and social democracy in the European periphery: paradoxes of the Turkish experience', Globalisations, vol. 4, no. 2, pp. 211-228.

Kirişçi, K. \& Winrow, G. M. (1997) The Kurdish question and Turkey: an example of a trans-state ethnic conflict, Frank Cass, London/Portland.

Koğacioğlu, D. (2003) 'Dissolution of political parties by the Constitutional Court in Turkey: judicial delimitation of the political domain', International Sociology, vol. 18, no. 1, pp. 258-276.

Koğacioğlu, D. (2004) 'Progress, unity, and democracy: dissolving political parties in Turkey', Law and Society Review, vol. 40, no. 3, pp. 433-461.

Linz, J. J. \& Stepan, A. (1997) Problems of Democratic Transition and Consolidation: Southern Europe, South America and Post-Communist Europe, Johns Hopkins University Press, Baltimore/ London.

Mardin, Ş. (1973) 'Centre-periphery relations: a key to Turkish politics?', Daedalus, vol. 102, no. 1, pp. 169-190.

Muller, M. (1996) 'Nationalism and the rule of law in Turkey: the elimination of Kurdish representation during the 1990s', in The Kurdish Nationalist Movement in the 1990s: Its Impact on Turkey and the Middle East, ed. R. Olson, University of Kentucky Press, Lexington, Kentucky, pp. 173-199.

Öniş, Z. (2000) 'Neoliberal globalisation and the democracy paradox: the Turkish general elections of 1999', Journal of International Affairs, vol. 54, no. 1, pp. 295-299.

Öniş, Z. (2001) 'Political Islam at the crossroads: from hegemony to co-existence', Contemporary Politics, vol. 7, no. 4, pp. 281-298.

Öniş, Z. (2006) 'The political economy of Turkey's Justice and Development Party', in The Emergence of a New Turkey: Democracy and the AK Parti, ed. M. H., Yavuz, University of Utah Press, Salt Lake City, 2006.

Özbudun, E. (1996) 'Turkey: how far from consolidation?', Journal of Democracy, vol. 7, no. 3, pp. $123-138$.

Özbudun, E. (2006) 'From political Islam to conservative democracy: the case of the Justice and Development Party in Turkey', South European Society and Politics, vol. 11, nos 3-4, pp. $543-557$. 
Pridham, G. (1990) 'Southern European democracies on the road to consolidation: a comparative assessment of the role of political parties', in Securing Democracy: Political Parties and Democratic Consolidation in Southern Europe, ed. G. Pridham, Routledge, London/New York, pp. $1-41$.

Pridham, G. (1995) 'The international context of democratic consolidation: Southern Europe in comparative perspective', in The Politics of Democratic Consolidation. Southern Europe in Comparative Perspective, eds R. Gunther, P. N. Diamandouros \& H. Puhle, Johns Hopkins University Press, Baltimore/London, pp. 166-203.

Partisi, Refah (1992) Aktüel Olaylar ve Milli Görüş [Current Events and National View], Ankara.

Somer, M. (2007) 'Moderate Islam and secularist opposition in Turkey: implications for the world, Muslims and secular democracy', Third World Quarterly, vol. 28, no. 7, pp. 1271-1289.

Taşkın, Y. (2008) 'AKP's move to "conquer" the centre-right: its prospects and possible impacts on the democratisation process', Turkish Studies, vol. 9, no. 1, pp. 53-72.

Ülsever, C. (2001) 'Change in conservative social strata is reflected in Fazilet', Turkish Daily News, 9 January. https://turkishdailynews.com.tr/archives.php?id=21364.

Watts, N. F. (1999) 'Allies and enemies: pro-Kurdish parties in Turkish politics, 1990-1994', International Journal of Middle East Studies, vol. 31, no. 4, pp. 631-656.

Yeğen, M. (1999) 'The Kurdish question in Turkish state discourse', Journal of Contemporary History, vol. 34 , no. 4 , pp. $555-568$.

Yavuz, H. (2000) 'Cleansing Islam from the public sphere', Journal of International Affairs, vol. 54, no. 1 , pp. $21-42$.

Yıldı, A. (2003) 'Politico-religious discourse of political Islam in Turkey: the parties of national outlook', Muslim World, vol. 93, no. 2, pp. 187-209.

Yılmaz, N. (2004) 'İslamcılık, AKP, Siyaset', Modern Türkiye'de Siyasi Düşünce, Cilt 6: İslamcılık, İletişim Yayınları, İstanbul, pp. 604-619.

Zürcher, E. J. (2005) Turkey: A Modern History, 3rd edn, I.B. Tauris, London/New York. 